\title{
RZP - pohled z druhé strany
}

V úvodníku časopisu 5/2019 nám kolega MUDr. et BC. Michal Ptáček popisuje své zkušenosti z praxe Rychlé zdravotnické pomoci (dále RZP), zejména ve vztahu knemocným dětem. Otevřeně priznává, že děti priváźejí pracovníci RZP na dětská oddělenítéměř vždy, a to jak s ohledem na diagnostickou a terapeutickou nejistotu, tak s ohledem na požadavky a častý tlak rodičů (1).

Rád konstatuji, že na našem pracovišti si všech pracovníků RZP vážíme (nejen jako dodavatele cca $25 \%$ pacientů) a máme pochopení pro jejich nelehkou práci. Pokud někdy přece jen nad privezeným pacientem s povzdechem zvedneme oči, pak to není tichá kritika záchranár̆ů, ale většinou těch, kdo prevoz požadují.

Každý, kdo se zajímá o organizaci akutní a urgentní medicíny, musel privítat ustavení RZP. Současně ale každý, kdo má trochu životních zkušeností, již dopredu tušil, že riziko zneuživáni se bliží téměř jistotě (a nemýlil se). A tak se RZP často volá u naprostých banalit z domova, ze škol, z terénu, táborů, restaurací i supermarketů, a pro cestu do nemocnice se velmi rychle ujal, kromè výhodného transportu „Senior - taxiza 40", ještě výhodnější pré$V O Z$ "RZP - taxi zdarma".

Je zřejmé, že se RZP potýká s řadou problémů, avšak patrně mezi ty nejpalčivější patři indikace prevozů, zejména dětských pacientů. V řadě prípadư se dají pochopit obavy rodičů o zdraví dětí, zejména těch nejmenšich. Současně však v řadě prípadů jde o zcela zjevné zneužívání. I méně vzdělaný rodič (natož pak dnešní vzdělaný, poučený internetem, erudovaný ve všech oblastech zdravotnictví) by mohl vědět, že svědění zadečku u pětiletého dítěte ve 3 hodiny $v$ noci není život ohrožujícím sta- vem, který vyžaduje okamžitý převoz na lůžkové dětské oddělení, stejně tak jako výsev tři papulek na hyždich, teplota 37,5 st., krátce trvající bolest hlavy nebo nevolnost. Matka, která zjistí, že nemá pro dítě s teplotou paralen, misto nákupu lékủ neváhá volat $R Z P$ - je to rychlejší, zdarma a bez námahy. Značnou část našíspolečné klientely tvoři pubertální dívky s tetanií. Zatímco před lety šlo o výjimečnýstav, dnes jsou nám tyto pacientky prìváženy témér pravidelnými linkami. Misto, aby byly doma zklidněny a dýchaly do igelitového pytlíku, jsou transportovány k hospitalizaci (podle predpisů za blikáni světel, prikkurtovány na lưžko s kanylou $\checkmark$ kubitě, do níz kape blahodárné $\mathrm{MgSO}_{4}$ ), takže na oddělení zachytíme maximálně naznačený Chvostkưv príznak, avšak pocit závažného stavu $\checkmark$ divkách často prètrvává, a tak se nám věrně vracejí opakovaně. Máme samozrejmè pochopení pro anxiozitu u první ataky, značná část recidiv by však mohla být vyřešena doma. Narůstajíci počet transportovaných opilých dorostenců dělá problémy jak pracovníkưm RZP, tak dětským oddělením.

Avšak uprímnost za uprímnost. Jen výjimečně ditě, dopravené $R Z P$, vracíme po vyšetření zpět, zejména když se prokáže banální onemocnění a již samotnévyšetrenenistačík uklidnění rodičủ. Naprostou většinu dětí, privivezených posádkou RZP, prijímáme k hospitalizaci. Samozrejmě děti jasně indikované, jiné „z principu“ (privezeny RZP!), některé rovněžz diagnostických rozpakü (zejména febrilníkojence), vnašem regionu však často iz důvodů jiných (sociálních, nedostupnosti dopravy, apod.).

Mám zato, žejakv praxi RZP, tak samotnélưžkovépediatrie, kromějižvzpomenutých diagnostických rozpaků a mínění rodičů, značnou roli hrají (verejně nepriznané) obavy z rizika forenznich důsledků, a to nejen oprávněných. Právníci se nám poněkud premnožili a tak občas dokážou udělat v oblasti léčebné péče „kauzu“i i nemožného. A tak vzniká retězec - nadbytečné volání RZP, nadbytečnépřevozy, nadbytečná vyšetření, nadbytečné hospitalizace. Je zrejmé, že takto pojatá liberalizace prístupu ke zdravotni péči zatěžuje a výrazně prodražuje celý systém. Avšak knápravějižjednou uvolněné praxe bude mít těžko někdo z politiků a organizátorů zdravotnictví odvahu, zejména sohledem na právníky, číhajícína jakýkoliv drobný konflikt či nesrovnalost.

Kolegu Ptáčka chci ujistit za sebe i vlastní pracoviště, že si činnosti pracovníků RZP nejen vážíme, ale také kladně hodnotíme stále se zlepšujici úroveň této nelehké služby, zejména co se týče závažných stavů, jako jsou poruchy vědomí, dušnost, krečové stavy, těžši úrazy, intoxikace, šokové stavy atd., které by měly být hlavní náplní péče RZP.

Co se týče zmíněných sekundárních převozü, ty jsou pro nás velkou pomocí, ale jinak se musíme ohradit. Vždy se snažíme, aby šlo o transporty indikované, předem vyjednané a pacienta vždy předáváme ve stabilizovaném stavu, adekvátnězajištěného tak, aby posádce RZP během cesty nekomplikoval život.

Děkujeme všem pracovníkům Zdravotnického záchranného systému za spolupráci a prejemejim, aby byli co nejméně zatěžováni banalitami a mohli svou odbornou pozornost a záchranárské uměni věnovat pacientưm, pro které byla tato služba koncipována. Těšíme se na dalšís spolupráci.

MUDr. Josef Grym

Pediatrické oddělení nemocnice SZZ Krnov grym.josef@szzkrnov.cz

\section{LITERATURA}

1. Ptáček, M. Dětský pacient (a jeho rodič) v sanitce. Pediatr. Praxi, 2019; 20(5): 283. 